\title{
Impact of dust accumulation on yield and yield components of soybean
}

\author{
Sharife HABIBPOUR ${ }^{1}$, Majid AMINI DEHAGHI ${ }^{1,2}$, Mohammad Eghbal GHOBADI ${ }^{3}$, Alaeddin KORDE- \\ NAEE $^{1}$
}

Received June 08,2020; accepted September 02, 2020.

Delo je prispelo 08. junij 2020, sprejeto 02. september 2020.

\begin{abstract}
Impact of dust accumulation on yield and yield components of soybean

Abstract: This study aimed to characterize if dust sprayed on soybean foliage impacts its yield and yield component characteristics. In 2017 and 2018, soybean [Glycine max (L.) Merr.] was planted using a factorial randomized complete block design with three replicates. Plants were sprayed with a $20 \mathrm{~g} \mathrm{~m}^{-2}$ of dust at four stages of the growth cycle, including third-node, the beginning of flowering, the beginning of podding, and the beginning of seed formation. Dust spraying was then continued twice weekly until the late full seed stage. Plant measurements included yield, yield components, stomatal conductance, peroxidase, and superoxide dismutase antioxidant enzymes activities. Results showed that depending on the time of application, the dust coverage created a range of yield loss in soybeans, most likely due to a reduction in stomatal conductance, grains plant ${ }^{-1}$ and 100-seed mass. Therefore, soybean fields that are regularly exposed to dust might be subjected to reduced yield.
\end{abstract}

Key words: peroxidase; superoxide dismutase; stomatal conductance
Vpliv nalaganja prahu na pridelek in njegove komponente pri soji

Izvleček: Namen raziskave je bil ugotoviti, če nalaganje prahu na listje soje vpliva na njen pridelek in njegove komponente. V letih 2017 in 2018 je bila posejana soja [Glycine max (L.) Merr.] v popolnem faktorskem poskusu s tremi ponovitvami. Rastline so bile posipane $\mathrm{z} 20 \mathrm{~g} \mathrm{~m}^{-2}$ prahu v štirih razvojnih fazah, ob pojavu tretjega nodija, $v$ začetku cvetenja, $v$ začetku razvoja strokov, in v začetku tvorbe semen. Prašenje je potekalo dvakrat tedensko do dokončnega razvoja semen. Meritve na rastlinah so obsegale meritev pridelka in njegovih komponent, prevodnost rež, in meritve aktivnosti antioksidacijskih encimov peroksidaze in superoksid dismutase. Rezultati so pokazali, da je odvisno od časa nanosa prah zmanjšal pridelek soje, najverjetneje zaradi zmanjšanja prevodnosti rež, zmanjšanja števila zrna na rastlino in mase stotih semen. Zaključimo lahko, da se zmanjša pridelek soje na poljih, ki so redno izpostavljena prašenju.

Ključne besede: peroksidaza; superoksid dismutaza; prevodnost rež

1 Shahed University, Department of Agronomy, Tehran, Iran

2 Corresponding author, e-mail: amini@shahed.ac.ir

3 Razi University, Department of Agronomy and Crop Science, Kermanshah, Iran 


\section{INTRODUCTION}

Natural factors and human activities lead to the production of dust particles. In Iran, the primary sources of dust storms, which influence the western and central regions, originate mainly from the deserts of Iraq and Saudi Arabia (Pirsaheb et al., 2014). In July 2009, the dust had adverse effects on Iran's agricultural lands and industrial areas (Hojati et al., 2012). In Yazd city, located in the deserts of Iran, the average airborne dust particles were more than $200 \mu \mathrm{g} \mathrm{m}^{-3}$ over five months, leading to a significant loss (between $3 \%$ to $30 \%$ ) in crops yield (Shahsavani et al., 2011). According to the meteorological organization statistics of Iran's Kermanshah province, dusty days occur mainly in spring and summer seasons (Doabi et al., 2017). Due to the dynamic characteristics of dust, particles with a diameter of fewer than ten $\mu \mathrm{m}$ can be transported by the wind for several thousands of kilometers (ZiaKhan et al., 2015).

Undoubtedly, dust causes many environmental impacts, such as loss of soil fertility or direct damages to crops, resulting in reduced agricultural products and, thus, large-scale economic losses (Walia et al., 2019). Besides, there is no regular natural removal of dust particles on the plant leaves by strong winds and rain, as rainfall is scarce, and the wind brings more dust rather than alleviating the situation (Zia-Khan et al., 2015). Dust-covered leaves provide less light for photosynthesis. Also, dust reduces the conductivity of the leaf stomata leading to decreased plant's biomass and yield. Zia-Khan et al. (2015) believe that dust accumulation on leaf surfaces induces water stress-like conditions.

Investigations on dust have mainly focused on the impacts of the different kinds of dust on morpho-physiological changes in plants (Drack \& Vázquez, 2018; Hatami et al., 2018; Siqueira-Silva et al., 2017; Siqueira-Silva et al., 2016). Stone crusher dust led to a decrease in grain yield of rice (Oryza sativa. L.) (Sharma \& Kumar, 2016) and gram (Cicer arietinum L.) (Sharma \& Kumar, 2015). Also, cement dust reduced yield, and one thousand-seed mass in wheat (Chaurasia et al., 2014; Hatami et al., 2018). A significant reduction in stomatal conductance has been reported under the influence of dust (Hirano et al., 1995; Zia-Khan et al., 2015). The smaller the particle size, the higher the effect of dust in reducing stomatal conductance so that fine particles less than five $\mu \mathrm{m}$ in diameter can interfere with the mechanism and function of the stomata (Singh et al., 2018).

Soybean (Glycine max L.) is one of the most important crops with many applications in food products, animal feed, and industries (Gnoinsky et al., 2019). It also has unique nutritional properties such as high content of proteins, oil, fiber, vitamins. Therefore the worldwide demand for soybean is at a high level (Lokuruka, 2011). Even with advances in farming practices, crop yields are still strongly linked to climate change (Glotter \& Elliott, 2016). Therefore, changes in field conditions, such as dust deposition, might affect crop performance and physiological properties.

Despite its strategic role, no study has been conducted on the impact of dust on soybean at different stages of growth under field conditions. Therefore, the objective of this study was to determine if the dust used at different growth stages influence soybean yield and yield components. Besides, stomatal conductance and the activities of peroxidase and superoxide dismutase antioxidant enzymes were assayed.

\section{MATERIALS AND METHODS}

\subsection{EXPERIMENTAL DESIGN}

The study was conducted in Kermanshah, Iran $\left(34^{\circ} 31^{\prime} \mathrm{N}, 47^{\circ} 09^{\prime} \mathrm{E}, 1319 \mathrm{~m}\right.$ above the sea level) during two consecutive years (2017-2018). The experiment was laid out in the form of a factorial randomized complete block design with three replicates (Fig. 1).

In each year, the experimental farm was divided into 24 plots (8 plots in each replicate). Each experimental plot consisted of 4 planting lines $4 \mathrm{~m}$ long and $50 \mathrm{~cm}$ apart. A distance of $0.5 \mathrm{~m}$ was). Soybean seeds (Glycine max 'Hobbit'), inoculated with Rhizobium japonicum Buchanan 1926 considered between the experimental plots, and $1.5 \mathrm{~m}$ between the experimental blocks (replicates was planted at a depth of $5 \mathrm{~cm}$ on rows $8 \mathrm{~cm}$ apart). The plants were watered by the surface irrigation method.

\subsection{DUST TREATMENT}

During the two years of the experiment, the effect of dust deposition on soybeans was investigated at four different time intervals (Fig. 2).

The control plants were rinsed with a hand sprinkler. Rinsing was done twice weekly to increase accuracy and ensure the absence of dust on control plants. Control plants were also rinsed by each occurrence of a natural dust storm. The water used for rinsing the control treatment was added to the soil of other plots to prevent possible errors. Dust particles had a natural origin and were collected using a gravimetric method 


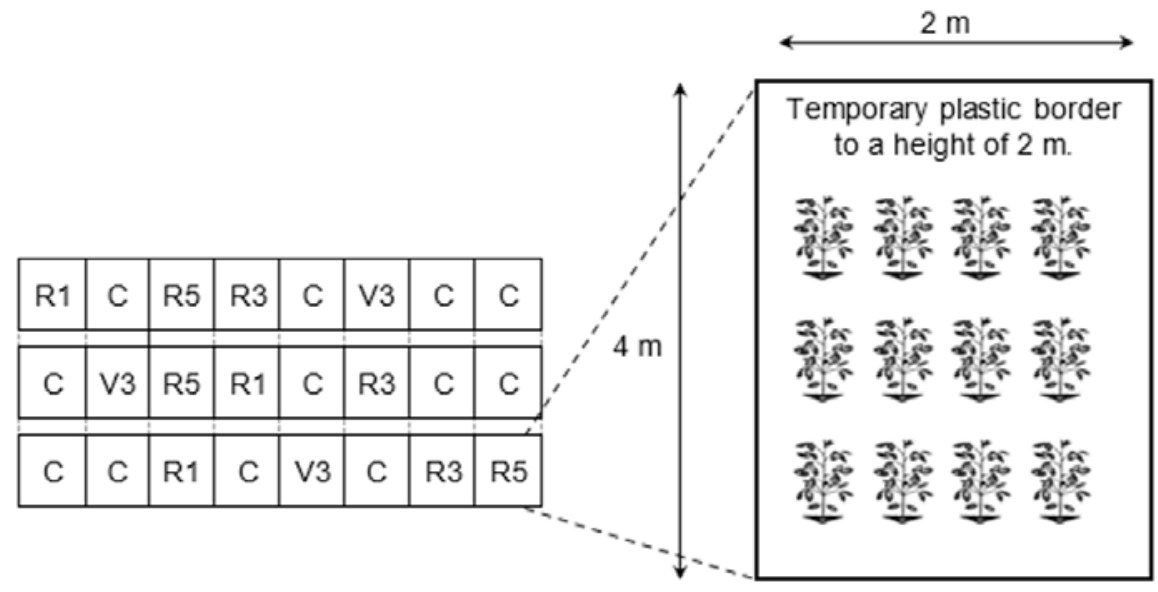

Figure 1: Schematic of the experimental design showing the treatments and the layout of the wind-proof spray chamber (zoom out). In each year of the experiment, the random distribution of treatments within the plots was different. The plants were exposed to dust from V3 (the third-node stage), R1 (the beginning of flowering), R3 (the beginning of podding), and R5 (the beginning seed formation); and $\mathrm{C}$ defines the control plots.

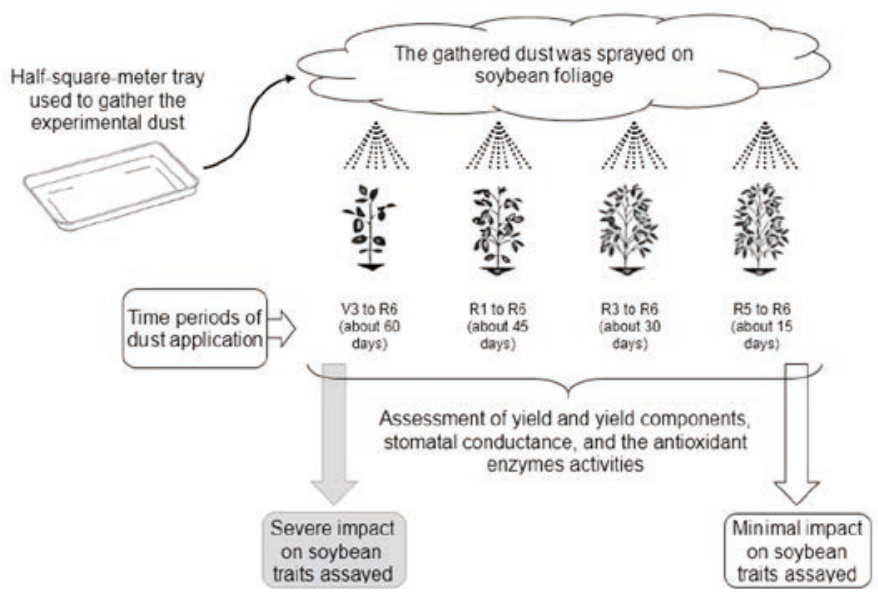

Figure 2: Schematic of whole of the experiment showing the dust application on soybeans at four different growth stages (time intervals).

from soybean cultivating sites exposed to dust storms for one year. For this purpose, half-square-meter trays were used to gather the dust deposited during dust

Table 1: Results of the chemical analysis (mg kg-1) of the experimental dust samples (Doabi et al., 2017)

\begin{tabular}{llll}
\hline Element & Minimum & Maximum & Mean \\
\hline $\mathrm{Zn}$ & 132 & 700 & 238.29 \\
$\mathrm{Cu}$ & 24 & 256 & 46.67 \\
$\mathrm{Ni}$ & 60 & 245 & 123.72 \\
$\mathrm{Cr}$ & 44 & 147 & 73.6 \\
$\mathrm{Mn}$ & 400 & 695 & 495.16 \\
$\mathrm{Fe}$ & 20,750 & 35,562 & $28,703.94$ \\
\hline
\end{tabular}

storms. Chemical analysis of the experimental dust was performed by Doabi et al. (2017) (Table 1).

\subsection{DUST APPLICATION}

In each year, dust spraying was done at four different times based on the plant growth stages, including V3 (third-node), R1 (the beginning of flowering), R3 (the beginning of podding), and R5 (the beginning of seed formation). Spraying was then continued until the late R6 (full seed) stage twice weekly (Fig. 2). At each event, a $20 \mathrm{~g} \mathrm{~m}^{-2}$ of dust was sprayed with a roughly uniform layer using a manual dust-generator. The machine was firstly calibrated based on the amount of dust accumulated on 
Table 2: Meteorological data during the two years of the experiment extracted from the meteorological station at the Razi Faculty of Agriculture, Kermanshah, Iran

\begin{tabular}{|c|c|c|c|c|c|c|c|c|c|c|c|c|}
\hline & \multicolumn{2}{|l|}{ Jun } & \multicolumn{2}{|l|}{ Jul } & \multicolumn{2}{|l|}{ Aug } & \multicolumn{2}{|l|}{ Sep } & \multicolumn{2}{|l|}{ Oct } & \multicolumn{2}{|l|}{ Nov } \\
\hline & 2017 & 2018 & 2017 & 2018 & 2017 & 2018 & 2017 & 2018 & 2017 & 2018 & 2017 & 2018 \\
\hline$R H(\%)$ & 17.27 & 24.49 & 12.16 & 13.23 & 10.88 & 14.86 & 11.74 & 15.62 & 21.59 & 42.67 & 50.44 & 70.75 \\
\hline $\operatorname{Max} T\left({ }^{\circ} \mathrm{C}\right)$ & 34.86 & 34.66 & 39.1 & 40.21 & 38.76 & 39.89 & 35.33 & 34.91 & 26.52 & 25.79 & 17.65 & 15.14 \\
\hline $\operatorname{Min} T\left({ }^{\circ} \mathrm{C}\right)$ & 13.52 & 13.55 & 18.26 & 19.07 & 18.75 & 16.89 & 13.15 & 13.24 & 7.95 & 10.59 & 3.81 & 5.65 \\
\hline Mean $T\left({ }^{\circ} \mathrm{C}\right)$ & 25.67 & 25.31 & 30.02 & 30.87 & 29.76 & 29.4 & 25.16 & 24.61 & 17.27 & 17.84 & 10.1 & 9.77 \\
\hline$A P(\mathrm{~mm})$ & 0 & 2.2 & 0 & 0 & 0 & 0 & 0 & 0.21 & 0.2 & 71.46 & 39.73 & 126.33 \\
\hline $\mathrm{DD}$ & 2 & 9 & 5 & 4 & 0 & 3 & 2 & 1 & 7 & 4 & 5 & 0 \\
\hline$A W S\left(\mathrm{~m} \mathrm{~s}^{-1}\right)$ & 3.14 & 2.94 & 3 & 3.36 & 3.12 & 2.95 & 2.68 & 2.55 & 2.83 & 2.61 & 2.33 & 2.74 \\
\hline
\end{tabular}

$R H$ : the relative humidity, T: Temperature, AP: Average Precipitation, $D D$ : The number of dusty days, AWS: Average wind speed

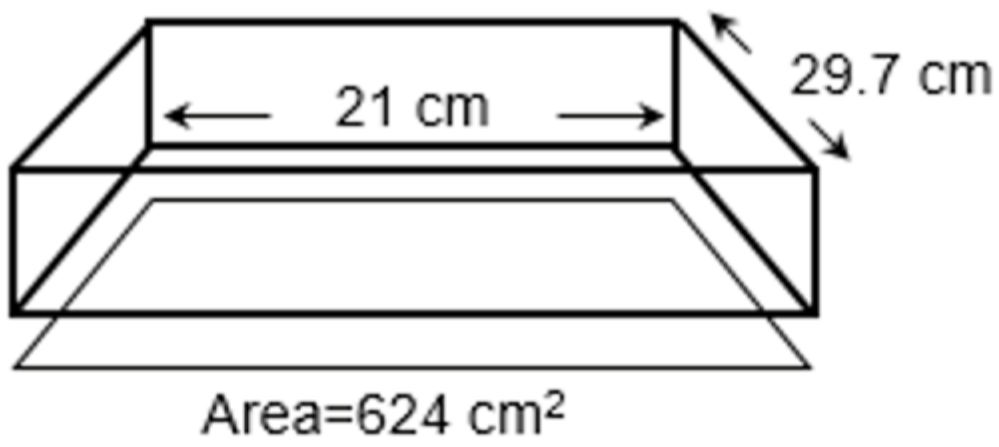

Figure 3: The sampling container used to calibrate the dust generator and to quantify the amount of dust deposited on plant leaves.

the surface of an A4 paper $\left(624 \mathrm{~cm}^{2}\right.$, Fig. 3). In addition, to determine the amount of dust deposited on plant leaves in each treatment, a rectangular cube glass container with a size of $27 \times 29.7 \mathrm{~cm}$ was placed inside each plot. After each treatment, the amount of dust deposited on the paper surface inside the container was measured (Fig. 3).

A wind-proof spray chamber was used to reduce wind disturbances during application and to ensure that dust was applied evenly to the treatment area, and also to avoid interference between the dust treatments (Fig. 1). The dust was sprayed when the air was constant without wind. After each rainfall, dust treatment was re-applied to soybean plants. Weather data from the weather station at the Razi Faculty of Agriculture (the nearest weather station) was recorded (Table 2).

\subsection{MEASUREMENTS}

In each year, yield and yield component characters were measured in the late full maturity (R8) stage when $95 \%$ of the pods have reached their full mature color. Antioxidant enzymes were measured in the late R6 stage when the plants had the maximum leaf area and height.

\subsubsection{Antioxidant enzymes activity}

The activity of the peroxidase enzyme (POD) was measured, according to MacAdam et al. (1992), with minor modifications. The reaction mixture contained $50 \mu \mathrm{g}$ guaiacol and $50 \mu \mathrm{l}$ of $3 \% \mathrm{H}_{2} \mathrm{O}_{2}$ in $0.1 \mathrm{mM}$ phosphate buffer. The reaction was started by adding $50 \mu \mathrm{l}$ of extract. The reaction was started by adding $50 \mu \mathrm{l}$ of extract. Then, the guaiacol peroxidase activity was determined spectrophotometrically by measuring the absorbance increase at $436 \mathrm{~nm}$ for 3 minutes at 15 -second intervals.

The activity of the superoxide dismutase (SOD) was determined consistent with Beauchamp and Fridovich (1971) method. A $50 \mu \mathrm{l}$ of the extract was dissolved in one 
$\mathrm{ml}$ of reaction buffer, including $50 \mathrm{mM}$ potassium phosphate buffer ( $\mathrm{pH} 7.8$ ), $75 \mu \mathrm{M}$ NBT, $13 \mathrm{ml}$ L-methionine $0.1 \mathrm{mM}$, EDTA, and two $\mathrm{mM}$ riboflavin. The mixture was placed in a light chamber for 15 minutes, and then its optical absorption rate was read at nm560 wavelength.

\subsubsection{Stomatal conductance}

The stomatal conductance ( $\mathrm{SC}, \mathrm{mmol} \mathrm{m}^{-2}$ ) was measured between 9-12 am by a leaf porometer (SC-1 Decagon Devices, Inc., USA) over ten leaves randomly selected from each plot.

\subsubsection{Yield and yield components}

Seeds of the third and fourth planting lines of each plot were harvested, and then weighed based on $12 \%$ moisture content (R8 stage), and converted to $\mathrm{kg} \mathrm{ha}^{-1}$. Besides, some of the most important soybean yield components were also measured, including Plant Height $(\mathrm{PH})$, Seeds Pod ${ }^{-1}$ (SPO), Seeds Plant ${ }^{-1}$ (SPL), Pods Plant ${ }^{-1}$ (PPL), 100-Seed Mass (HSM), and Harvest Index (HI).

\subsubsection{Statistical analysis}

Data were analyzed using the PROC GLM procedure of SAS software V. 9.1 (SAS Institute, Cary, NC, USA). A pairwise comparison of means was performed using the t-test (LSD) method at the 0.05 level of probability. All data collected during the two growing seasons were evaluated in a combined analysis format and then analyzed for differences among treatments over the two years, and presented in the combined form not individually within each year.

\section{RESULTS}

Table 2 shows the metrological data. In 2017, there were 2, 5, and 0 days with dust in the January, July, and August, respectively, coincide with V3-R1 stages, while there were 2, 7, and 5 days with dust for September, October, and November, respectively, coincide with R5-R8 stages. Therefore, in 2017, there were more days with dust at the end of the growth phase. Conversely, there were more days with dust in the early months of the growing season than the final months for the second year of the experiment. Furthermore, the wind speed on the ground was similar during both years of the investigation. Due to higher rainfall, the relative humidity was relatively higher in the second year.

\subsection{EFFECT ON YIELD AND YIELD COMPO- NENTS}

Results showed that dust by stage interaction had significant effects on yield and yield-related traits assayed (Table 3 and Fig. 4). As shown in Table 4 and Figure 4, the responses of yield and yield-related traits to dust application had the same behavior. First, their values differed significantly between dust-treated and control plants, second, the lowest values were obtained when the dust was applied from the V3 stage, and third, after the control, the highest values were observed when the plants were exposed to dust from the R5 stage. On average, over the two years, soybean seed yield varied from $2040.84 \mathrm{~kg}$ $\mathrm{ha}^{-1}$ to $481.42 \mathrm{~kg} \mathrm{ha}^{-1}$. Also, on average, seed yield declined significantly by $73.00 \%, 53.33 \%, 42.73 \%$, and $34.47 \%$ in plots dusted from V3, R1, R3, and R5 stages, respectively (Fig. 4). Similarly, the same reduction schemes were also found for PH, SPL, PPL, SPO, HSM, and HI (Table 4). The analysis of standardized regression showed that SPL and HSM with 0.66 and 0.35 had the most significant positive direct effect on seed yield, respectively, while $\mathrm{PH}$ and PPL with -0.13 , and -0.10 had negative direct effects on seed yield (data not shown).

\subsection{EFFECT ON ANTIOXIDANT ENZYMES AC- TIVITY AND STOMATAL CONDUCTANCE}

The activity of antioxidant enzymes differed significantly between dust-treated and control plants. As shown in Figures 5 and 6, the antioxidants responses to dust application had the same pattern in both POD and SOD. Both enzymes assayed showed a significant activity under dust treatment and peaked when the plants were exposed to dust from the V3 stage. However, the antioxidants showed less activity when spraying was done in the later stages of growth (Figs 5 and 6). POD activity was 32, 25,12 , and 6 times higher than the control when plants were exposed to dust form V3, R1, R3, and R5 stages, respectively.

Similarly, SOD activity increased by $88.08 \%$, $65.51 \%, 49.31 \%$, and $29.28 \%$ for those plants exposed to dust form V3, R1, R3, and R5 stages, respectively. Therefore, under the influence of dust, the activity of POD showed a further increase compared with SOD.

On average, over the two years, the stomatal conductance varied from 9.91 to $26.22 \mathrm{~mol} \mathrm{CO}_{2} \mathrm{~m}^{-2} \mathrm{~s}^{-1}$ (Table 4). Exposure to dust resulted in a significant loss in 


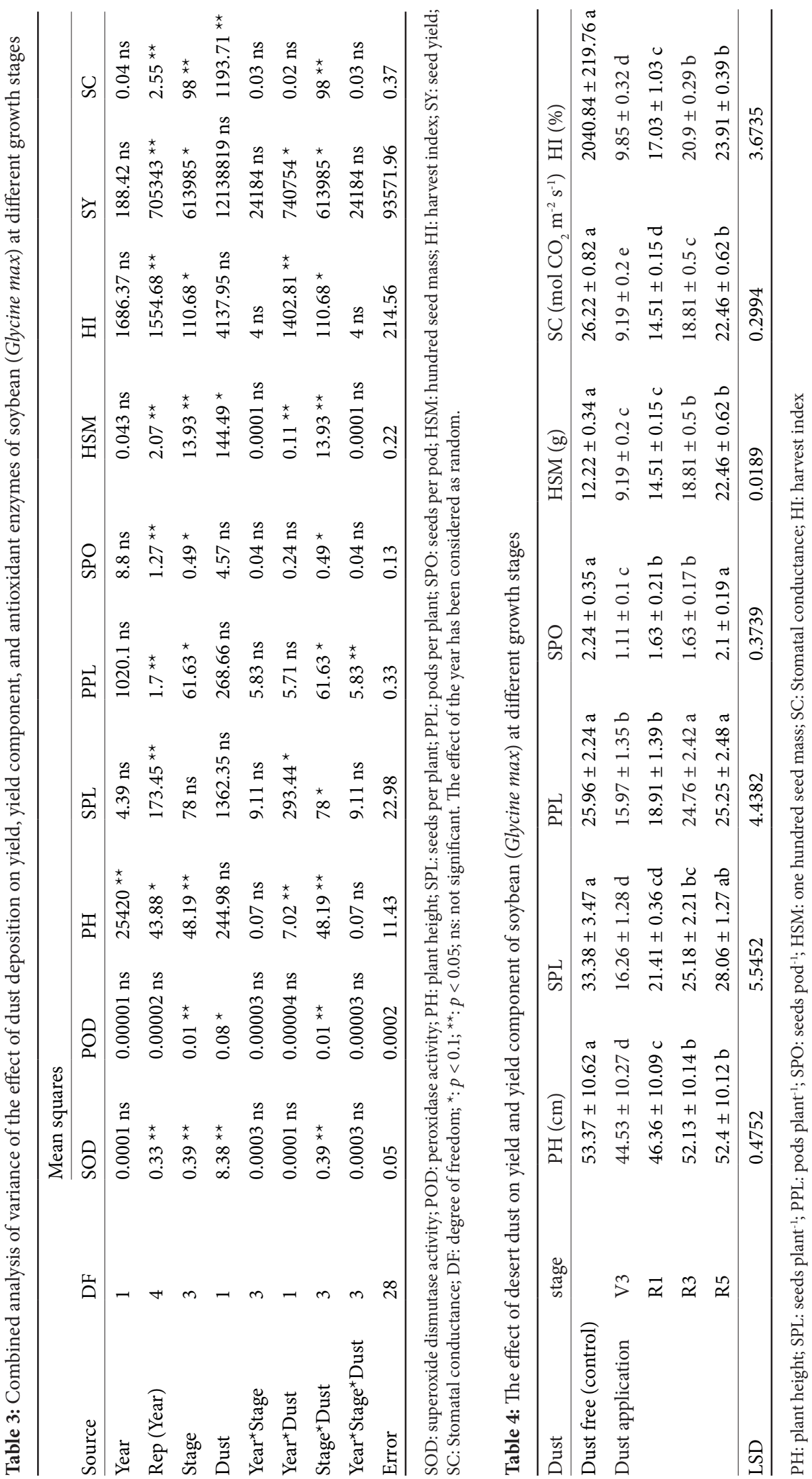


SC compared to the control plants (Table 4). Besides, the highest considerable decline in SC was found for plots treated with dust from the V3 stage (about $64.95 \%$ decrease, compared with control).

At each of the growth stages, the dust was sprayed weekly from V3 (the third-node stage), R1 (the beginning of flowering), R3 (the beginning of podding), R5 (the beginning of seed formation), until the late full seed stage (R6).

In each column, means that do not share a letter are significantly different according to the LSD test $(\alpha=$ 0.05).

Compared with the control, the application of dust from the R1, R3, and R5 stages resulted in $44.64 \%$, $28.24 \%$, and $14.34 \%$ decrease in stomatal conductance, respectively. Therefore, SC was significantly higher for plots dusted from the R5 stage. The study of the Pearson correlation coefficients showed that $\mathrm{SY}$ was positively correlated with SPL, PPL, SPO, HSM, HI, and SC. In contrast, the correlations between SY with POD and SOD were significantly negative (Table 5).

The antioxidant enzymes were negatively correlated with yield and yield components. Conversely, yield and yield components were positively correlated with stomatal conductance. Pods plant ${ }^{-1}$ was negatively correlated with PH. Principal components analysis revealed that in 2017, HI, SY, and HSM had the highest load on the first principal component, respectively. Similarly, in 2018, HSM, PP, and SY had also the highest load on PC1, respectively. Considering that the $\mathrm{PC} 1$ justifies the most

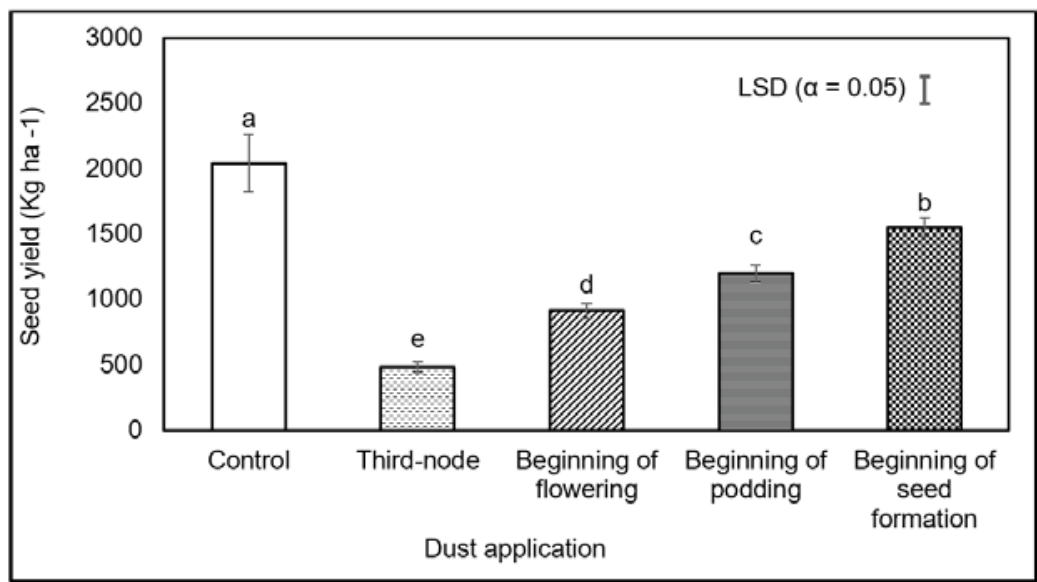

Figure 4: The effect of desert dust deposition on soybean seed yield. The dust was sprayed weekly on soybean leaves from each of the four different growth stages shown in the figure to the late full seed stage. The letters shown at the top of the columns indicate significant differences based on the LSD method $(\alpha=0.05)$

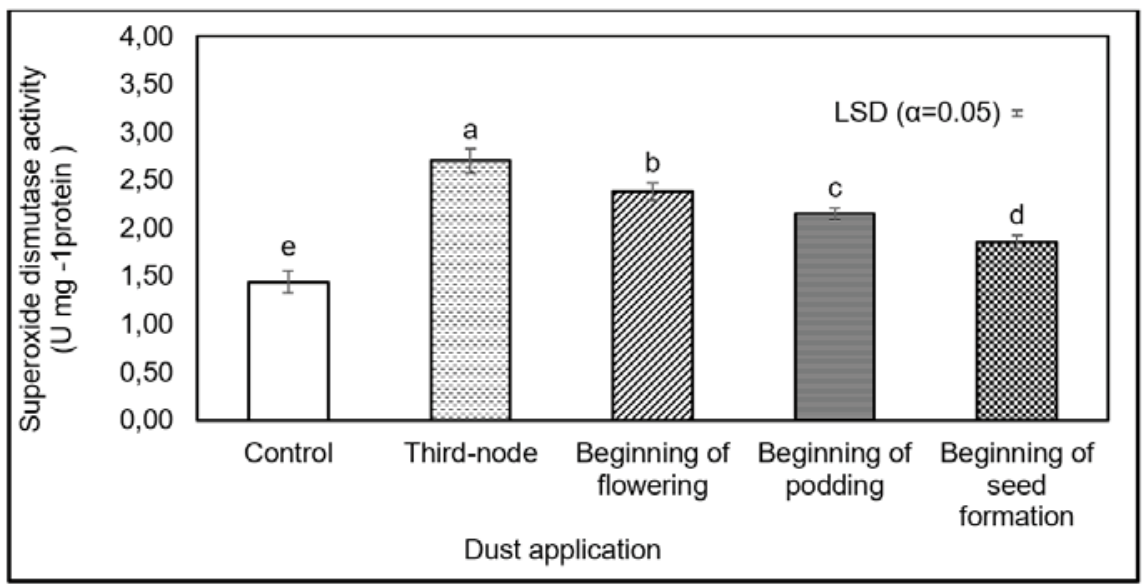

Figure 5: The effect of desert dust deposition on superoxide dismutase activity in soybean leaves. The dust was sprayed weekly on soybean leaves from each of the four different growth stages shown in the figure to the late full seed stage. The letters shown at the top of the columns indicate significant differences based on the LSD method ( $\alpha=0.05)$ 


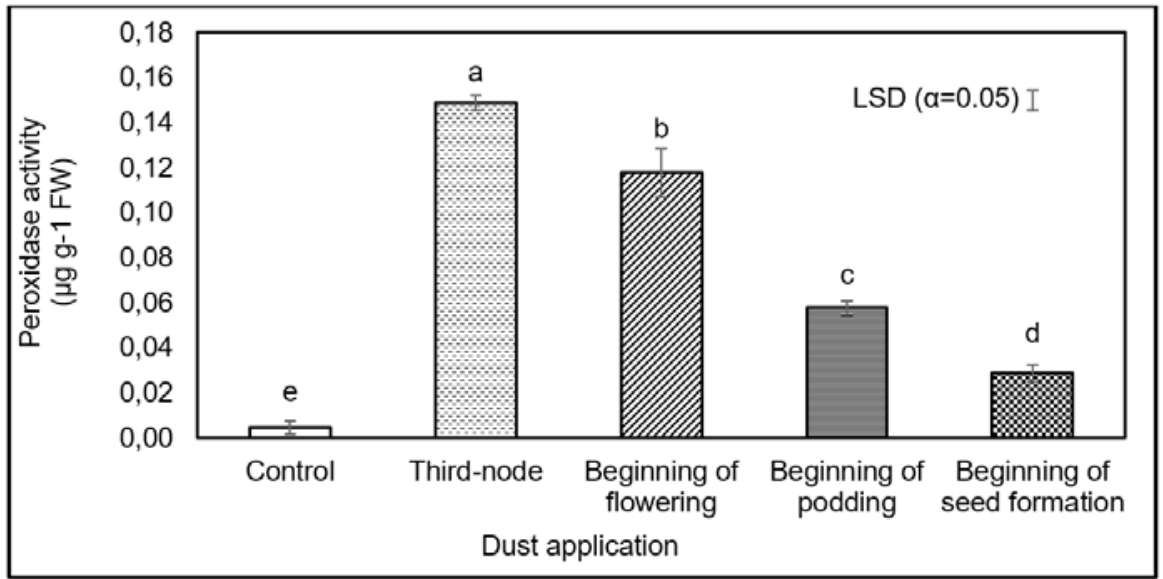

Figure 6: The average peroxidase activity in soybean leaves under the impact of desert dust deposition. The dust was sprayed weekly on soybean leaves from each of the growth stages shown in the figure to the full seed stage. The letters shown at the top of the columns indicate significant differences based on the LSD method $(\alpha=0.05)$

Table 5: Pairwise Pearson correlations between the traits studied on soybean (Glycine max L.) under the impact of dust deposition at different growth stages

\begin{tabular}{llllllllll}
\hline & SOD & POX & PH & SPL & PPL & SPO & HSW & HI & SY \\
\hline POX & $0.87^{* *}$ & 1 & & & & & & & \\
PH & -0.11 & -0.12 & 1 & & & & & & \\
SPL & $-0.44^{* *}$ & $-0.72^{* *}$ & 0.1 & 1 & & & & & \\
PPL & $-0.49^{* *}$ & $-0.59^{* *}$ & $-0.66^{* *}$ & $0.378^{*}$ & 1 & & & & \\
SPO & $-0.62^{* *}$ & $-0.53^{* *}$ & $0.69^{* *}$ & 0.15 & -0.14 & 1 & & & \\
HSW & $-0.89^{* *}$ & $-0.95^{* *}$ & 0.15 & $0.7^{* *}$ & $0.55^{* *}$ & $0.62^{* *}$ & 1 & & \\
HI & -0.22 & $-0.48^{* *}$ & -0.27 & $0.86^{* *}$ & $0.49^{* *}$ & -0.21 & $0.48^{* *}$ & 1 & \\
SY & $-0.62^{* *}$ & $-0.84^{* *}$ & 0.09 & $0.97^{* *}$ & $0.46^{* *}$ & $0.315^{*}$ & $0.84^{* *}$ & $0.82^{* *}$ & 1 \\
SC & $-0.86^{* *}$ & $-0.97^{* *}$ & 0.14 & $0.72^{* *}$ & $0.58^{* *}$ & $0.51^{* *}$ & $0.96^{* *}$ & $0.47^{* *}$ & $0.83^{* *}$ \\
\hline
\end{tabular}

${ }^{*}$ and ${ }^{* *}$ indicate that correlation is significant at the $0.05,0.01$ level, respectively.

SOD: superoxide dismutase activity, POX: peroxidase activity, PH: plant height; SPL: seeds plant ${ }^{-1}$; PPL: pods plant ${ }^{-1}$; SPO: seeds pod-1; HSM: one hundred seed mass; HI: harvest index; SY: seed yield, SC: Stomatal conductance.

variance therefore, HSM and SY experienced the highest variations under the influence of dust accumulation in both years (Fig. 7).

SOD: superoxide dismutase activity; POD: peroxidase activity; PH: plant height; SPL: seeds per plant; PPL: pods per plant; SPO: seeds per pod; HSM: hundred seed weight; HI: harvest index; SY: seed yield; SC: Stomatal conductance.

\section{DISCUSSION}

In this study, dust resulted in a significant decrease in yield and yield components of soybean compared with the control. Previous studies have shown that dust pollution resulted in a yield loss in cotton (Abdullaev \&
Sokolik, 2020), potato (Tomar et al., 2018), black gram (Phaseolus mungo L.) (Babu et al., 2018), rice (Sett, 2017; Sharma \& Kumar, 2016), and grapevine (Karami et al., 2017). Hatami et al. (2018) studied the effects of desert dust on yield and yield components of cowpea and found that exposure to desert dust significantly decreased biological yield and seed yield of cowpea by $28.3 \%$ and $25.6 \%$, respectively, compared with normal conditions. Little research has specifically looked at the impacts of dust on soybeans yield as a result of dust being present on leaves (Gnoinsky et al., 2019). Our results revealed that SPL and HSM had the most significant positive direct effects on seed yield. As a result, these traits were the main responsible for the majority of variation in SY. Therefore, the decrease in SY could be related to the significant reduction in these two traits. The correlation coefficients 


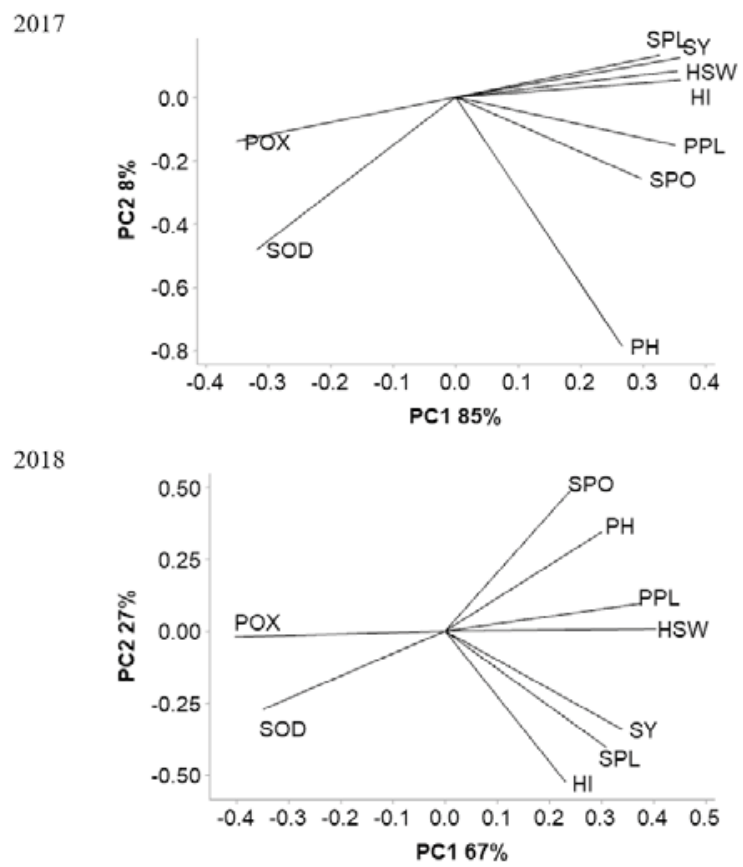

Figure 7: Principal components analysis of the soybean traits under the influence of dust accumulation studied in 2017 (the upper figures) and 2018 (bottom figures)

between SY and yield-related traits confirmed this inference. It has been suggested that under the impact of dust, the acidic secretion of stigma turned into alkaline, a condition that is unfavorable for pollen germination, which leads to poor fertilization and decrease in SPL as well as SPO (Borka, 1981; Sett, 2017). It seems that under the influence of dust, the drop observed in PPL, and HSM was mainly caused by a defect in the plant's photosynthetic system due to clogging of the stomata and, as a result, a decrease in gas exchange. Interference in the gas exchanges between the leaf and the air is one of the most critical consequences of dust accumulation on the leaves. At the same time, the photosynthesis process requires gas exchange through the stomata of the leaves. Thus any disturbance in the stomata pathways can cause problems with photosynthesis (FeleKari et al., 2017). Besides, it was evident that dusty leaves receive less light because of the shading effects due to the deposition of suspended particulate on the leaf surface. Therefore, dust-covered leaves will face a decrease in photosynthesis.

The results of this study indicated that dusted plants had significantly smaller SC compared with control. The reason seems to be the clogging of the stomata above the leaf surface. Dust particles interfere with the mechanism and operation of the stomata, resulting in a significant reduction in gas exchange. Similar to this result, Zia-Khan et al. (2015) reported a substantial decrease in SC of the dusted plants compared to the control. In one study, dusted leaves of Triticum aestivum L. and Pisum sativum L. had a more number of blocked stomata significantly as compared with control leading to decreased SC (Rahman, 2015).

Results showed that the dusty environment induced the activity of the antioxidant enzymes. In plants, the activity of antioxidant enzymes generally increases under stress conditions. Also, the increase in antioxidant enzyme activity is significantly correlated with the severity of stress (Pilon et al., 2006; Zhang et al., 2014). Antioxidant enzymes work together to eliminate excess reactive oxygen species (ROS), thus protecting the structures and functions of cellular components. SOD is an essential constituent of the antioxidant defense system in plants which. SOD catalyzes the dismutation of superoxide into oxygen and hydrogen peroxide (Tyagi et al., 2019). Consistent with our results, several studies reported that SOD activity increased in response to dust deposition in plants (Erdal \& Demirtas, 2010; Siqueira-Silva et al., 2017; Siqueira-Silva et al., 2016). POD, another antioxidant enzyme, is broadly distributed among plant tissues and plays a significant role in various growth, development, and senescence processes. POD cooperates with SOD to eliminate superoxide and hydrogen peroxide to protect proteins and lipids against ROS (Zhang et al., 2014). The results of this study showed that POD activity increased significantly with the increase in SOD. The induction of the POD activity under dust pollution has also been re- 
ported earlier in several tree species (Keller, 1974), some wild dicotyledonous plants including Chrozophora plicata A. Juss., and Croton bonplandianum R. Br., Clerodendron inerme Gaertn; Solanum torvum Swartz.; Calotropis procera R. Br. (Sarkar et al., 1986), and grapevine (Vitis vinifera L.) (Karami et al., 2017).

\section{CONCLUSIONS}

We found that applying the dust from the vegetative growth stage caused the highest decrease in soybean yield and yield components, and at the same time, led to the highest increase in the antioxidant enzyme activities. Compared to different growth stages, the occurrence of dust at the V3 stage causes plants to be exposed to dust for more extended periods. On the other hand, most crops become increasingly tolerant during later stages of growth (Pirasteh et al., 2014). Therefore, the occurrence of dust at the vegetative stage led to more significant adverse effects on soybean. In conclusion, it was found that the dust accumulation on soybean leaf surfaces reduced stomatal conductance, yield, and yield components. Loss in grains plant ${ }^{-1}$ and one hundred seed mass was the main reason for the reduction in grain yield. More importantly, the results of this study show that yield and yield components were adversely affected by dust deposits during the vegetative period.

\section{REFERENCES}

Abdullaev, S. F., \& Sokolik, I. N. (2020). Assessment of the influences of dust storms on cotton production in Tajikistan. In G. Gutman, J. Chen, G. M. Henebry, \& M. Kappas (Eds.), Landscape Dynamics of Drylands across Greater Central Asia: People, Societies and Ecosystems (pp. 87-105). Springer International Publishing. https://doi.org/10.1007/978-3030-30742-4_6

Babu, P. H., Rao, K. N., Jayalalitha, K., \& Ali, M. A. (2018). Assessment of different dust pollutants effect on total chlorophyll content, transpiration rate and yield of blackgram (Phaseolus mungo L.). International Journal of Current Microbiology and Applied Sciences, 7(4), 2890-2896. https://doi.org/10.20546/ijcmas.2018.704.329

Beauchamp, C., \& Fridovich, I. (1971). Superoxide dismutase: Improved assays and an assay applicable to acrylamide gels. Analytical Biochemistry, 44(1), 276-287. https://doi. org/10.1016/0003-2697(71)90370-8

Borka, G. (1981). Effect of cement kiln dust on maize plant. Acta Agronomica Hungarica, 30, 289-295.

Chaurasia, S., Karwariya, A., \& Gupta, A. D. (2014). Impact of cement industry pollution on morphological attributes of wheat (Triticum Species) Kodinar Gujarat, India. Journal of Environmental Science, Toxicology and Food Technology, 8(7), 84-89. https://doi.org/10.9790/2402-08728489

Doabi, S. A., Afyuni, M., \& Karami, M. (2017). Multivariate statistical analysis of heavy metals contamination in atmospheric dust of Kermanshah province, western Iran, during the spring and summer 2013. Journal of Geochemical Exploration, 180, 61-70. https://doi.org/10.1016/j.gexplo.2017.06.007

Drack, J. M. E., \& Vázquez, D. P. (2018). Morphological response of a cactus to cement dust pollution. Ecotoxicology and Environmental Safety, 148, 571-577. https://doi. org/10.1016/j.ecoenv.2017.10.046

Erdal, S., \& Demirtas, A. (2010). Effects of cement flue dust from a cement factory on stress parameters and diversity of aquatic plants. Toxicology and Industrial Health, 26(6), 339343. https://doi.org/10.1177/0748233710369235

FeleKari, H., Ghobadi, M. E., Ghobadi, M., Jalali-Honarmand, S., \& Saeidi, M. (2017). Effect of dust deposition on yield and yield components of chickpea (Cicer arietinum L.) under rain fed and supplemental irrigation conditions in Kermanshah. Journal of Agroecology, 9(2), 535-544. https://doi. org/10.22067/jag.v9i2.54549

Glotter, M., \& Elliott, J. (2016). Simulating US agriculture in a modern dust bowl drought. Nature Plants, 3(1), 16193. https://doi.org/10.1038/nplants.2016.193

Gnoinsky, A., Hargiss, C. L. M., Prischmann-Voldseth, D., \& DeSutter, T. (2019). Road dust fails to impact soybean physiology and production. Agronomy Journal, 111(4), 17601769. https://doi.org/10.2134/agronj2018.10.0640

Hatami, Z., Rezvani Moghaddam, P., Rashki, A., Mahallati, M. N., \& Habibi Khaniani, B. (2018). Effects of desert dust on yield and yield components of cowpea (Vigna unguiculata L.). Archives of Agronomy and Soil Science, 64(10), 14461458. https://doi.org/10.1080/03650340.2018.1440081

Hirano, T., Kiyota, M., \& Aiga, I. (1995). Physical effects of dust on leaf physiology of cucumber and kidney bean plants. Environmental Pollution, 89(3), 255-261. https://doi. org/10.1016/0269-7491(94)00075-O

Hojati, S., Khademi, H., Faz Cano, A., \& Landi, A. (2012). Characteristics of dust deposited along a transect between central Iran and the Zagros Mountains. CATENA, 88(1), 27-36. https://doi.org/10.1016/j.catena.2011.09.002

Karami, L., Ghaderi, N., \& Javadi, T. (2017). Morphological and physiological responses of grapevine (Vitis vinifera L.) to drought stress and dust pollution. Folia Horticulturae, 29(2), 231-240. https://doi.org/10.1515/fhort-2017-0021

Keller, T. (1974). The use of peroxidase activity for monitoring and mapping air pollution areas. European Journal of Forest Pathology, 4(1), 11-19. https://doi. org/10.1111/j.1439-0329.1974.tb00407.x

Lokuruka, M. (2011). Effects of processing on soybean nutrients and potential impact on consumer health: An overview. African Journal of Food, Agriculture, Nutrition and Development, 11(4), 5000-5017. https://doi.org/10.4314/ ajfand.v11i4.69170

MacAdam, J. W., Sharp, R. E., \& Nelson, C. J. (1992). Peroxidase Activity in the Leaf Elongation Zone of Tall Fescue. II. Spatial Distribution of Apoplastic Peroxidase Activity in 
Genotypes Differing in Length of the Elongation Zone, 99(3), 879-885. https://doi.org/10.1104/pp.99.3.879

Pilon, M., Abdel-Ghany, S. E., Cohu, C. M., Gogolin, K. A., \& Ye, H. (2006). Copper cofactor delivery in plant cells. Current Opinion in Plant Biology, 9(3), 256-263. https://doi. org/10.1016/j.pbi.2006.03.007

Pirsaheb, M., Zinatizadeh, A., Khosravi, T., Atafar, Z., \& Dezfulinezhad, S. (2014). Natural airborne dust and heavy metals: a case study for kermanshah, Western Iran (2005-2011). Iranian Journal of Public Health, 43(4), 460-470.

Rahman, J. K. (2015). Response of two crop plants to dust deposition. ZANCO Journal of Pure and Applied Sciences, 27(2), 1-6. https://doi.org/10.21271/zjpas.v27i2.144

Sarkar, R. K., Banerjee, A., \& Mukherji, S. (1986). Acceleration of peroxidase and catalase activities in leaves of wild dicotyledonous plants, as an indication of automobile exhaust pollution. Environmental Pollution Series A, Ecological and Biological, 42(4), 289-295. https://doi.org/10.1016/01431471(86)90013-9

Sett, R. (2017). Responses in plants exposed to dust pollution. Horticulture International Journal, 1(1). https://doi. org/10.15406/hij.2017.01.00010

Shahsavani, A., Yarahmadi, M., Jafarzade Haghighifard, N., Naimabadie, A., Mahmoudian, M. H., Saki, ... Naddafi, K. (2011). Dust storms: Environmental and health impacts [Review Article]. Journal of North Khorasan University of Medical Sciences, 2(4), 45-56. https://doi.org/10.29252/jnkums.2.4.45

Sharma, S. B., \& Kumar, B. (2015). Effects of stone crusher dust pollution on growth performance and yield status of gram (Cicer arietinum L.). International Journal of Current Microbiology and Applied Sciences, 4(3), 971-979.

Sharma, S. B., \& Kumar, B. (2016). Effects of stone crusher dust pollution on growth performance and yield status of rice (Oryza sativa. L). International Journal of Current Microbiology and Applied Sciences, 5(5), 796-806. https://doi. org/10.20546/ijcmas.2016.505.080

Singh, N., Shrivastava, R., \& Mishra, A. (2018). Influence of leaf dust deposition on chlorophyll content of Bougainvil- lea spectabilis and Lanatana camara growing in vicinity of jaypee cement plant, rewa (mp). International Journal of Information Research and Review, 5(9), 5685-5688.

Siqueira-Silva, A. I., Pereira, E. G., Lemos-Filho, J. P. d., Modolo, L. V., \& Paiva, E. A. S. (2017). Physiological traits and antioxidant metabolism of leaves of tropical woody species challenged with cement dust. Ecotoxicology and Environmental Safety, 144, 307-314. https://doi.org/10.1016/j. ecoenv.2017.06.041

Siqueira-Silva, A. I., Pereira, E. G., Modolo, L. V., Lemos-Filho, J. P., \& Paiva, E. A. S. (2016). Impact of cement dust pollution on Cedrela fissilis Vell. (Meliaceae): A potential bioindicator species. Chemosphere, 158, 56-65. https://doi. org/10.1016/j.chemosphere.2016.05.047

Tomar, D., Khan, A. A., \& Ahmad, G. (2018). Response of potato plants to foliar application of cement dust. Tropical Plant Research, 5(1), 41-45. https://doi.org/10.22271/tpr.2018. v5.11.007

Tyagi, S., Shumayla, Singh, S. P., \& Upadhyay, S. K. (2019). Role of superoxide dismutases (SODs) in stress tolerance in plants. In: S. P. Singh, S. K. Upadhyay, A. Pandey, \& S. Kumar (Eds.), Molecular Approaches in Plant Biology and Environmental Challenges (pp. 51-77). Springer Singapore. https://doi.org/10.1007/978-981-15-0690-1_3

Walia, K., Aggarwal, R., \& Bhardwaj, S. (2019). Leaf dust accumulation and its relationship with biochemical parameters of different plant species growing along national highway-22, India. International Journal of Chemical Studies, 7(1), 1386-1390.

Zhang, X., Yin, H., Chen, S., He, J., \& Guo, S. (2014). Changes in antioxidant enzyme activity and transcript levels of related genes in Limonium sinense Kuntze seedlings under $\mathrm{NaCl}$ stress. Journal of Chemistry, 2014, 749047. https://doi. org/10.1155/2014/749047

Zia-Khan, S., Spreer, W., Pengnian, Y., Zhao, X., Othmanli, H., He, X., \& Müller, J. (2015). Effect of Dust deposition on stomatal conductance and leaf temperature of cotton in Northwest China. Water, 7(1), 116-131. https://doi. org/10.3390/w7010116 